\title{
PENTINGNYA IMPLEMENTASI RASIO AKTIVITAS, RASIO LAVERAGE BERBASIS RASIO LIKUIDITAS DAN RASIO RENTABILITAS PADA BUMN DALAM UPAYA ANALISIS EVALUASI EFISIENSI PENGGUNAAN MODAL KERJA
}

\author{
Adya Hermawati \\ E-mail : wati_wati38@yahoo.co.id
}

\begin{abstract}
Abstrak: Tingkat efisien atau tidak efisien penggunaan modal erja pada produk pegadaian menjadi fokus dalam penelitian ini. Alat analisis yang digunakan meliputi rasio likuiditas, rasio aktivitas, rasio laverage dan rasio rentabilitas. Hasil perhitungan bahwa rasio likuiditas tahun 2007 sampai dengan tahun 2010 menunjukkan likuiditas perusahaan tidak stabil, tidak efisien artinya ada kewajiban keuangan lain yang masih belum terpenuhi pada waktunya. Jika ditinjau dari segi profitabilitas yaitu kemampuan perusahan dalam menghasilkan laba belum tentu dikatakan efisien, karena semakin banyak perusahaan menyimpan uang kas di tangan berarti semakin banyak dana yang menganggur. Hasil perhitungan rasio aktivitas perputaran piutang tahun 2007 sampai dengan tahun 2010 di nilai efisien. Karena dalam jangka waktu yang ditentukan oleh perusahaan perputaran uang pinjaman dari nasabah telah kembali.Sedangkan perputaran modal kerja dari tahun 2007 sampai dengan 2010 sudah efisien, artinya kemampuan dana yang tertanam dalam modal kerja berputar di perusahaan sudah efisien sesuai dengan apa yang di harapkan perusahaan.Demikian hasil rasio laverage bahwa kemampuan perusahaan dalam meтепuhi sетиа kewajiban keuangannya dinilai efisien karena jumlah dari total aktiva tahun 2007 sampai dengan tahun 2010 lebih besar dibanding dengan jumlah total hutangnya. Kondisi Rentabilitas tahun 2007 sampai dengan 2010 menunjukkan perusahaan efisien karena kemampuan perusahaan dengan seluruh modal yang bekerja di dalamnya untuk menghasilkan laba masih stabil. Rentabilitas lebih penting dari masalah laba, karena laba yang besar belumlah merupakan ukuran bahwa perusahaan itu telah dapat bekerja secara efisien
\end{abstract}

Key Words: Rasio Aktivitas, Rasio Leverage, Rasio Likuiditas, Rasio Rentabilitas, Efisiensi Modal Kerja

Abstract: Rate efficient or inefficient use of capital ining the pawnshop products become the focus in this study. The analysis tools include liquidity ratios, activity

Adya Hermawati, Dosen Manajemen Fakultas Ekonomi Universitas Widyagama Malang 
ratios, profitability ratios and the ratio laverage. The results of the calculations that the liquidity ratio of 2007 to 2010 showed the company's liquidity is unstable, inefficient means there are still other financial obligations have not been met on time. If the terms of the profitability of the company's ability to generate earnings may not be said to be efficient, as more and more companies keep cash on hand means more funds are idle. The results of the calculation of the ratio of turnover activities in 2007 to 2010 in value efficiently. Because in the time period specified by the loan company turnover of customers have kembali.Sedangkan working capital turnover from 2007 to 2010 has been streamlined, which means that the ability of the funds that are embedded in the company's working capital revolving been streamlined in accordance with what is expected of the company. thus the results of the ratio laverage the company's ability to meet all its financial obligations rated efficient because the amount of total assets in 2007 to 2010 is greater than the total. Conditions Profitability in 2007 to 2010 demonstrated its efficient because the ability of the company to the entire capital to work on it to make a profit is still stable. Profitability is more important than the problem of profit, because the profit is not yet a measure that the company has been able to work efficiently.

Key Words: Working Capital Efficiency

\section{PENDAHULUAN}

Peraturan Pemerintah RI No 103 Tahun 2000 (pasal 10): Modal Perusahaan umum pegadaian berasal dari kekayaan negara yang dipisahkan dari anggaran dan belanja negara dan tidak terbagi atas saham-saham. Modal kerja yang sudah diberikan pemerintah tersebut harus dapat dialokasikan secara tepat untuk mendukung kegiatan dalam rangka mencapai maksud dan tujuan perusahaan.

Perusahaan umum pegadaian sebagai BUMN yang diberi tugas dan wewenang dalam menyelenggarakan kegiatan usaha menyalurkan uang pinjaman atas dasar hukum gadai, untuk mengatasi agar masyarakat yang sedang membutuhkan uang tidak jatuh ketangan renternir. Oleh karena itu perusahaan pegadaian menyediakan pinjaman uang melalui beberapa macam variasi produk yaitu: Produk KCA (Kredit Cepat Aman) dan KREASI (Kredit Angsuran Sistem Fidusia) dengan prosedur yang mudah, cepat dan dengan biaya yang dibebankan lebih ringan. Hal ini sesuai dengan salah satu tujuan dari Perum pegadaian dalam memberi pinjaman melalui produk-produk pegadaian dengan motto Mengatasi Masalah Tanpa Masalah.

Pada dasarnya untuk melakukan kegiatan operasionalnya tersebut, Perum Pegadaian sangat membutuhkan modal kerja sebagai kekayaan atau aktiva yang diperlukan oleh perusahaan untuk melakukan kegiatan sehari-hari dan yang selalu berputar. Untuk dapat menjaga agar perusahaan dapat terus tumbuh dan berkembang, modal kerja perusahaan merupakan salah satu faktor terpenting untuk menjaga kelangsungan hidup perusahaan dalam jangka panjang.

Modal kerja yang digunakan untuk membiayai penjualan produk pegadaian diharapkan dengan menggunakan dasar rasio keuangan untuk mengukur efisiensi modal kerja yang tepat dapat meminimalisasi atau 
menghindari adanya kelebihan dan kekurangan modal kerja yang tidak efektif, sehingga akan dapat menghasilkan jumlah laba yang efisien.

Agar perusahaan dapat menjalankan usahanya dan modal kerja dapat digunakan secara tepat dan efisien maka kelancaran piutang dan perputaran piutang pada modal kerja harus dimonitor dan dikendalikan secara seksama. Hal ini penting untuk perusahaan yang sedang berkembang, sebab kelancaran piutang dan perputaran piutang pada modal kerja dapat berpengaruh terhadap jumlah investasi pada perusahaan, terutama karena adanya perubahan pada sisi aktiva yang sangat cepat.

Kelebihan jumlah aktiva lancar bisa berakibat pada realisasi pengembalian investasi yang dibawah standar yang ditentukan sehingga akan memperoleh capital again (laba yang cukup). Sedangkan perusahaan dengan aktiva lancar yang terlalu sedikit dapat menimbulkan kekurangan dan kesulitan dalam kelancaran operasi perusahaan.

Modal kerja sebagai aktiva lancar yang mewakili bagian dari investasi yang berputar dari satu bentuk kebentuk lainnya dalam rangka melaksanakan suatu usahanya. Agar modal kerja yang dimiliki oleh perusahaan dapat mencukupi kegiatan operasional perusahaan (dalam hal ini untuk membiayai produk pegadaian berupa kredit). Maka perusahaan perlu untuk menetapkan strategi modal kerja sebagai salah satu keputusan paling penting yang harus dibuat berhubungan dengan aktiva lancar dan pasiva lancar, adalah bagaimana pasiva lancar akan digunakan untuk membiayai aktiva lancar.

Modal kerja yang tidak efisien dalam penggunaannya akan mengakibatkan turunnya keuntungan. Apabila modal kerja yang disediakan oleh suatu perusahaan berlebihan, hal ini menunjukan adanya dana yang tidak produktif dalam penggunaannya dan sebenarnya merupakan kerugian bagi perusahaan tersebut. Karena kesempatan untuk memperoleh laba yang lebih besar telah disiasiakan, begitu juga sebaliknya apabila modal kerja yang disediakan tidak cukup akan menjadi penyebab utama gagalnya suatu usaha.

Untuk mencukupi pembiayaan produk yang dibutuhkan perusahaan diperlukan modal kerja yaitu : modal kerja permanen dan modal kerja variable atau musiman, sehingga dari hubungan antara aktiva lancar dan aktiva tetap dengan dana permanen dan musiman yang dibutuhkan dapat diketahui berapa besar ekstimasi kebutuhan dana, baik kebutuhan dana tetap maupun kebutuhan dana musiman.

Agar jumlah ekstimasi kebutuhan modal kerja perusahaan dapat dialokasikan secara tepat, maka perusahaan perlu membuat rencana keuangan dan ramalan penjualan. Dari ramalan penjualan maka perusahaan dapat memperkirakan ekstimasi kebutuhan modal kerja yang akan digunakan untuk membiayai produk perusahaan. Ramalan penjualan sendiri merupakan prediksi penjualan perusahaan pada suatu periode tertentu didasarkan pada data eksternal dan atau data internal serta digunakan sebagai input untuk membuat rencana penjualan dan merupakan input utama untuk proses perencanaan keuangan jangka pendek. Dengan demikian yang harus diperhatikan oleh perusahaan adalah bagaimana agar modal kerja yang ada dapat memenuhi segala aktivitas perusahaan secara tepat dan efisien sehingga dapat diperoleh laba. 


\section{TINJAUAN PUSTAKA \\ Pengertian Efisiensi}

Menurut Syamsi (1994:7) Efisiensi merupakan suatu ukuran keberhasilan yang dinilai dari segi besarnya sumber/biaya untuk mencapai hasil dari kegiatan yang dijalankan. Efisiensi tanpa tolak ukur ditinjau dari beberapa segi yaitu: a) ditinjau dari segi produktifitas/hasil (out): dengan pengorbanan yang sama (tertentu) hasilnya berbeda, semakin tinggi hasilnya, maka semakin efisien. Efisiensi yang optimal adalah perbandingan yang terbaik antara pengorbanan yang di berikan dengan hasil yang dicapai, b) ditinjau dari segi penghematan /pengorbanan (input) maka dengan pengorbanan yang berbeda memberikan hasil yang sama (tertentu), semakin kecil pengorbanan semakin efisien.

Sedangkan Efisiensi dengan tolak ukur ditinjau dari beberapa segi yaitu: a) ditinjau dari segi hasil (produktifitas/output): Efisiensi adalah perbandingan antar hasil minimum yang ditetapkan dengan hasil riil yang dicapainya. Dikatakan efisien apabila hasil riil nya lebih besar daripada hasil minimal yang dibakukan. Dikatakan normal apabila hasil riil yang dicapainya sama dengan hasil minimal yang ditetapkan. Dikatakan tidak efisien apabila hasil riilnya lebih kecil dari hasil minimal yang ditetapkan. b) ditinjau dari segi pengorbanan (penghematan/input) maka efisiensi adalah perbandingan antara pengorbanan maksimal yang ditetapkan dan pengorbanan riilnya. Dikatakan efisien apabila pengorbanan riilnya lebih kecil dari pada pengorbanan maksimum yang ditetapkan. Dikatakan tidak efisien apabila pengorbanan riilnya lebih besar dari pada pengorbanan maksimal yang ditetapkan, ukuran normal dimaksudkan juga sebagai efisien (Syamsi, 1994 : 7).

\section{Pengertian Modal Kerja}

Menurut Ridwan S. Sundjaja dan Inge Barlian (2003:187) Modal kerja adalah aktiva lancar yang mewakili bagian dari investasi yang berputar dari satu bentuk ke bentuk lainnya dalam melaksanakan suatu usaha, modal kerja tersebut berupa kas/bank, surat-surat berharga yang mudah diuangkan (misal: giro, cek, deposito), piutang dagang dan persediaan yang tingkat perputarannya tidak melebihi 1 tahun atau jangka waktu operasi normal perusahaan.

Menurut Bambang Riyanto (1998:57) mengenai pengertian modal kerja ini dapat dikemukakan adanya beberapa konsep yaitu:

a. Konsep Kuantitatif

Konsep ini mendasarkan pada kuantitas dari dana yang tertanam dalam unsur aktiva lancar dimana aktiva ini merupakan aktiva yang sekali berputar kembali dalam bentuk semula atau aktiva dimana dana yang tertanam di dalamnya akan dapat bebas lagi dalam waktu yang pendek. Dengan demikian modal kerja menurut konsep ini adalah keseluruhan dari jumlah aktiva lancar.

Modal kerja dalam pengertian ini sering disebut modal kerja bruto (Gross Working Capital).

b. Konsep Kualitatif

Sebagian dari aktiva lancar yang benar-benar dapat digunakan untuk membiayai kegiatan operasi perusahaan tanpa mengganggu likuiditasnya, 
yaitu yang merupakan kelebihan aktiva lancar diatas hutang lancarnya. Modal kerja dalam pengertian ini sering disebut modal kerja netto (Net Working Capital)

c. Konsep Fungsional

Konsep ini mendasarkan pada fungsi dari dana dalam menghasilkan pendapatan (income). Ada sebagian dana yang digunakan dalam suatu periode accounting tertentu yang seluruhnya langsung menghasilkan pendapatan bagi periode tertentu (current income), dan ada sebagian dana lain yang juga digunakan selama periode tersebut tetapi tidak seluruhnya digunakan untuk menghasilkan current income. Berdasarkan konsep ini maka definisi modal kerja sebagai dana yang digunakan selama periode accounting yang dimaksudkan untuk menghasilkan current income yang sesuai dengan maksud utama didirikan perusahaan tersebut.

\section{Manfaat Modal Kerja}

Modal kerja harus cukup jumlahnya untuk membiayai pengeluaran- pengeluaran operasi perusahaan sehari-hari. Menurut Drs. S Munawir, (2002:116) penggunaan modal kerja yang efisien dapat memberikan manfaat serta keuntungan antara lain:

1. Melindungi perusahaan terhadap krisis modal kerja karena turunnya nilai dari aktiva lancar, misalnya seperti adanya kerugian karena debitur tidak membayar

2. Memungkinkan perusahaan untuk dapat membayar semua kewajibannya jangka pendeknya tepat pada waktunya.

3. Memungkinkan perusahaan untuk dapat memiliki persediaan dalam jumlah yang cukup sehingga perusahaan dapat melayani permintaan konsumennya.

4. Memungkinkan bagi perusahaan untuk memberikan syarat kredit yang lebih menguntungkan kepada langganannya

5. Memungkinkan perusahaan untuk dapat beroperasi secara ekonomis dan lebih efisien

\section{METODE}

\section{Rancangan Penelitian}

Penelitian ini menyajikan penelitian deskriptif dengan menggunakan jenis penelitian studi kasus. Menurut Marzuki (2002:7) penelitian deskriptif adalah penelitian yang dilakukan dengan melukiskan keadaan obyek atau persoalannya. Jenis penelitian deskriptif merupakan metode yang menggambarkan dan menafsirkan data mengenai keadaan saat ini dan kecenderungan yang akan terjadi pada masa yang akan datang.

Melalui metode ini, peneliti ingin mengetahui seberapa jauh tingkat kinerja rasio keuangan sebagai alat analisis untuk menganalisis penggunaan modal kerja pada Perum Pegadaian Cabang Rembang dengan menggunakan data-data keuangan yang berasal dari laporan keuangan Perum Pegadaian Cabang Rembang. Dari definisi tersebut maka dapat diketahui bahwa penelitian ini lebih 
bersifat pada penjelasan terhadap fenomena-fenomena yang terjadi.

\section{Teknik Analisa}

Dalam menganalisis data menggunakan dua cara yaitu:

1. Data kualitatif

Data yang berbentuk uraian kata yang meliputi sejarah singkat perusahaan.

2. Data kuantitatif

Data yang berbentuk angka dalam bentuk laporan keuangan berupa neraca, laporan laba rugi, serta laporan rekapitulasi pinjaman, taksiran dan biaya administrasi. Dari data tersebut kemudian dianalisis untuk mendapatkan kesimpulan.

Adapun perhitungan untuk mengetahui efisiensi modal kerja perusahaan dapat dilakukan dengan melalui langkah-langkah sebagai berikut:

1. Menghitung besarnya masing-masing rasio yaitu rasio likuiditas, rasio aktivitas, perputaran modal kerja, rasio leverage, rasio rentabilitas.

2. Menentukan standart efisien dan tidak efisien.

\section{PEMBAHASAN}

Analisis Ratio Likuiditas

\section{Tabel 1}

Keadaan Current Ratio dan Cash Ratio

Tahun 2007-2010

\begin{tabular}{|c|c|c|}
\hline Tahun & $\begin{array}{c}\text { Current } \\
\text { Ratio }\end{array}$ & Cash Ratio \\
\hline 2007 & $113 \%$ & $118 \%$ \\
2008 & $137 \%$ & $324 \%$ \\
2009 & $102 \%$ & $384 \%$ \\
2010 & $903 \%$ & $132 \%$ \\
\hline
\end{tabular}

Sumber: Data skunder diolah

Dari table 1 di atas dapat diketahui bahwa angka ratio likuiditas, jika ditinjau dari current ratio menunjukkan bahwa pada tahun 2007 sebesar 113\%, tahun 2008 sebesar 137\%, tahun 2009 sebesar 102\%, dan tahun 2010 sebesar 903\%. Berarti perusahaan belum mampu melunasi kewajiban jangka pendek yang segera harus dibayar, bahwa patokan umum menentukan current ratio ideal adalah 200\% maka dapat dikatakan bahwa current ratio itu baik. Namun pada tahun 2010 terlihat bahwa keadaan current ratio mengalami kenaikan yang sangat tinggi sehingga dikatakan efisien karena melebihi current ratio ideal. Namun perlu ditandaskan bahwa hal tersebut diatas hanya merupakan keadaan umum dan ratio tersebut dapat berubah setiap saat.

Sedangkan berdasarkan perhitungan cash ratio terlihat bahwa pada tahun 2007 sebesar $118 \%$, tahun 2008 sebesar 324\%, tahun 2009 sebesar 384\% dan pada tahun 2010 sebesar $132 \%$. Pada patokan umum menganggap bahwa cash ratio 
tidak boleh kurang dari angka $20 \%$. Cash ratio pada perhitungan di atas dapat dikatakan baik karena berada diatas angka standart, dimana perusahaan mempunyai kemampuan dalam mengembalikan kewajiban-kewajiban untuk tahun mendatang

Jika ditinjau dari segi penjaminan hutang lancar dapat dikatakan bahwa cash ratio yang tinggi adalah baik, namun ditinjau dari segi profitabilitas yaitu kemampuan perusahaan dalam menghasilkan laba belum tentu. Dikatakan demikian karena semakin banyak perusahaan menyimpan uang kas ditangan berarti semakin banyak dana yang menganggur.

\section{Analisis Rasio Aktivitas}

\section{Tabel 2}

Keadaan Perputaran Piutang Tahun 2007-2010

\begin{tabular}{|c|c|c|c|}
\hline Tahun & $\begin{array}{c}\text { Batas Max } \\
\text { Perputaran } \\
\text { Piutang }\end{array}$ & $\begin{array}{c}\text { Perputaran } \\
\text { Piutang }\end{array}$ & $\begin{array}{c}\text { Rata-Rata } \\
\text { Piutang } \\
\text { (Rp) }\end{array}$ \\
\hline 2007 & 3 kali & 3,36 kali & 2.642 .432 .421 \\
2008 & 3 kali & 3,20 kali & 3.987 .840 .171 \\
2009 & 3 kali & 3,65 kali & 5.254 .326 .669 \\
2010 & 3 kali & 3,56 kali & 5.180 .148 .256 \\
\hline
\end{tabular}

Sumber: Data skunder diolah

Pada Perum Pegadaian Cabang Rembang sejak berubah nama menjadi Perum sampai saat ini di tetapkan bahwa batas maximum adalah per 120 hari/4 bulan. Maka tingkat perputaran piutang yang diharapkan adalah sesuai dengan batas maximum yang ditentukan sebelumnya pada setiap periode 4 bulan. Apabila dilihat dari tingkat perputaran piutang selama tahun 2007 sampai dengan 2010 dengan masing-masing sebesar 3,36 kali, 3,20 kali, 3,65 kali dan 3,56 kali dapat dinyatakan bahwa perputaran piutang sudah efisien karena sesuai dengan batas mximum yang telah ditetapkan oleh perusahaan yaitu sebesar 3 kali per 120 hari/4 bulan. Hal ini menunjukkan adanya perputaran piutang yang efektif. Namun jika pada saat-saat tertentu bahkan pada saat tak terduga terjadi piutang tak tertagih maka perusahaan dapat menutupi dengan melakukan pelelangan pada barang jaminan yang di miliki nasabah sebagai resiko karena nasabah sendiri tidak bisa melunasi kewajiban-kewajibannya sehingga dikhawatirkan dapat menganggu jalannya kegiatan operasional perusahaan. Piutang tak tertagih ini akan terjadi disebabkan karena nasabah menunda-nunda pembayaran dan itu juga sangat berpengaruh terhadap tingkat perputaran piutang. 
Tabel 3

Keadaan Rata-Rata Pengumpulan Piutang

Tahun 2007-2010

\begin{tabular}{|c|c|c|c|c|}
\hline Tahun & $\begin{array}{c}\text { Realisasi } \\
\text { Perputaran } \\
\text { Piutang }\end{array}$ & $\begin{array}{c}\text { Min } \\
\text { Pengumpulan } \\
\text { Piutang }\end{array}$ & $\begin{array}{c}\text { Max } \\
\text { Pengumpulan } \\
\text { Piutang }\end{array}$ & $\begin{array}{c}\text { Realisasi rata- rata } \\
\text { pengumpulan } \\
\text { piutang }\end{array}$ \\
\hline 2007 & $3,36 \mathrm{kali}$ & 15 hari & 120 hari & 35,7 hari \\
2008 & $3,20 \mathrm{kali}$ & 15 hari & 120 hari & 37,5 hari \\
2009 & $3,65 \mathrm{kali}$ & 15 hari & 120 hari & 32,9 hari \\
2010 & 3,56 kali & 15 hari & 120 hari & 33,7 hari \\
\hline
\end{tabular}

Sumber: Data skunder diolah

Dari tabel 3 diatas nampak bahwa perputaran piutang tahun 2007 sebesar 3,36 kali, tahun 2008 sebesar 3,20 kali, tahun 2009 sebesar 3,65 kali dan tahun 2010 sebesar 3,56 kali mengalami keadaan yang sangat stabil karena perputaran piutang pada perusahaan batas maximumnya adalah sebesar 3 kali dalam kurun waktu 4 bulan.

Apabila pengumpulan piutang pada Perum Pegadaian Cabang Rembang tepat pada waktunya maka modal kerja akan dapat digunakan dengan baik sehingga kelangsungan hidup perusahaan akan terjamin dan kesempatan untuk menaikan volume penjualan/omset dan keuntungan akan lebih terealisasikan. Berikut akan diuraikan berapa besar modal kerja yang tertanam dalam pengumpulan piutang.

\section{Analisis Perputaran Modal Kerja}

Perputaran modal kerja pada tahun 2008 jika dibandingkan dengan tahun 2007 sampai dengan tahun 2010 merupakan perolehan tingkat modal kerja rendah. Hal ini dapat dinyatakan bahwa modal kerja pada perusahaan tidak efisien. Pada tahun 2007 penggunaan modal kerja perusahaan efisien sebesar 3,02 kali, pada tahun 2008 mengalami penurunan menjadi sebesar 2,87 kali, perputaran modal kerja yang rendah menunjukkan adanya kelebihan modal kerja yang mungkin disebabkan rendahnya piutang atau adanya saldo kas yang terlalu besar (Munawir 2002:80). Pada tahun 2009 naik kembali menjadi 3,52 kali dan pada tahun 2010 sebesar3,35 kali. Dengan adanya fluktuasi kenaikan dan penurunan kemudian kenaikan lagi pada perputaran modal kerja tersebut menunjukkan bahwa penggunaan modal kerja dalam penggelolaan perusahaan masih belum efisien. Penggunaan modal kerja dikatakan efisien apabila keadaan modal kerja dari tahun ke tahun mengalami kenaikan atau dalam keadaan yang stabil.

\section{Analisis Rasio Leverage}

Pada hasil perhitungan keadaan rasio total hutang terhadap total asset pada tahun 2007 artinya $1,24 \%$ dari total aktiva itu dibiayai menggunakan dana yang berasal dari hutang. Pada tahun 2008 sebesar 1,71\%, tahun 2009 sebesar 2,61\% 
dan pada tahun 2010 sebesar 2,61\% dari masing-masing tahun tersebut dari total aktiva itu dibiayai menggunakan dana yang berasal dari hutang.

Pada hasil perhitungan rasio solvabilitas pada tahun 2007 sebesar $8,00 \%$, tahun 2008 sebesar 5,83\%, tahun 2009 sebesar 3,81\% dan pada tahun 2010 sebesar 4,78\%. Maka artinya dari setiap 1 rupiah hutang pada tahun 2007 dijamin oleh sebesar Rp8,00 aktiva pada tahun 2008 artinya setiap 1 rupiah hutang di jamin oleh Rp5,83 aktiva pada tahun 2009 setiap 1 rupiah hutang dijamin oleh Rp3,81 aktiva dan pada tahun 2010 setiap 1 rupiah dijamin Rp4,78 aktiva. Dan perusahaan akan mengalami solvabilitas apabila total aktivanya melebihi total hutangnya. Pada tahun 2007 sampai dengan tahun 2010 perusahaan mengalami solvabilitas di karenakan jumlah dari total aktiva lebih besar dari pada jumlah total hutangnya.

\section{Analisis Ratio Rentabilitas}

\section{Tabel 4}

Keadaan Profit Margin Dan Rentabilitas Modal Sendiri Tahun 2007-2010

\begin{tabular}{|c|c|c|}
\hline Tahun & Profit Margin & Rentabilitas Modal \\
\hline 2007 & $3,94 \%$ & $61,16 \%$ \\
2008 & $6,95 \%$ & $60,78 \%$ \\
2009 & $7,16 \%$ & $60,76 \%$ \\
2010 & $8,78 \%$ & $36,85 \%$ \\
\hline
\end{tabular}

Sumber: Data skunder diolah

Jumlah profit margin pada tahun 2010 lebih tinggi dibandingkan tahun 2007, 2008 dan 2009. pada tahun 2007 profit margin sebesar 3,94\%, tahun 2008 mengalami kenaikan menjadi 6,95\%, tahun 2009 mengalami peningkatan lagi menjadi sebesar 7,16\% dan pada tahun 2010 juga terus mengalami kenaikan menjadi $8,78 \%$. Profit margin akan dikatakan efisien jika dari tahun ketahun selalu mengalami kenaikan dan memenuhi standart efisiensi yaitu sebesar $25 \%$. Usaha untuk memperbesar profit margin yaitu dengan menambah biaya usaha sampai tingkat tertentu di usahakan tercapainya tambahan sales atau dengan kata lain tambahan sales harus lebih besar dari pada tambahan operating expenses, dengan mengurangi pendapatan dari sales sampai tingkat tertentu diusahakan adanya penggunaan operating expences yang sebesar-besarnya atau dengan kata lain mengurangi biaya usaha relative lebih besar dari pada berkurangnya pendapatan dari sales. Meskipun jumlah sales selama periode tertentu berkurang, tetapi oleh karena disertai dengan berkurangnya operating expenses yang lebih sebanding maka akibatnya ialah bahwa profit margin akan semakin besar.

\section{KESIMPULAN} Kesimpulan

Berdasarkan pembahasan di atas dapat diambil kesimpulan sebagai berikut:

1. Rasio Likuiditas 
Berdasarkan hasil perhitungan rasio likuiditas yang di ukur dengan menggunakan current ratio dan cash ratio tahun 2007 sampai dengan tahun 2010 menunjukkan likuiditas perusahaan tidak stabil karena pada current rasio yang selalu mengalami naik turun dari tahun ketahun. Pada current ratio di sini likuiditas juga tidak efisien karena tidak memenuhi standart ideal current ratio yaitu $200 \%$, sedangkan ini berarti bahwa pada tahun-tahun sebelumnya bahwa masih ada kewajiban keuangan lain yang masih belum terpenuhi tepat pada waktunya. Sedangkan dari ukuran perhitungan cash ratio jika di tinjau dari segi penjaminan hutang lancar dapat dikatakan memiliki likuiditas yang efisien hal itu terlihat dari tahun ketahun selalu mengalami kenaikan, namun cash ratio jika ditinjau dari segi profitabilitas yaitu kemampuan perusahan dalam menghasilkan laba belum tentu dikatakan efisien, karena semakin banyak perusahaan menyimpan uang kas di tangan berarti semakin banyak dana yang menganggur.

2. Rasio Aktivitas

Berdasarkan hasil perhitungan rasio aktivitas yang di ukur dengan perputaran kas, perputaran piutang dari tahun 2007 sampai dengan tahun 2010 di nilai efisien. Karena dalam jangka waktu yang ditentukan oleh perusahaan yaitu 4 bulan batas maximum terjadi 3 kali perputaran uang pinjaman dari nasabah telah kembali.

3. Perputaran Modal Kerja

Perputaran modal kerja dari tahun 2007 sampai dengan 2010 dengan membandingkan antara kas, batas minimum dan batas maximum piutang dari tahun ke tahun menunjukkan bahwa perputaran modal kerja sudah efisien, yang berarti kemampuan dana yang tertanam dalam modal kerja berputar di perusahaan dalam jangka waktu batas max 4 bulan sama dengan 3 kali sudah efisien sesuai dengan apa yang di harapkan perusahaan.

4. Rasio Leverage

Berdasarkan hasil perhitungan rasio laverage yang diukur dengan nilai rasio total hutang terhadap total assets serta tingkat solvabilitas kemampuan perusahaan dalam memenuhi semua kewajiban keuangannya dinilai efisien karena jumlah dari total aktiva dari tahun 2007 sampai dengan tahun 2010 lebih besar dibanding dengan jumlah total hutangnya.

5. Tingkat rentabilitas

Berdasarkan hasil perhitungan rentabilitas yang diukur dengan rasio rentabilitas modal sendiri dan profit margin dari tahun 2007 sampai dengan 2010 menunjukkan perusahaan efisien karena kemampuan perusahaan dengan seluruh modal yang bekerja di dalamnya untuk menghasilkan laba masih stabil, jika dilihat berdasarkan perhitungan profit margin dari tahun ketahun selalu meningkat, sedang pada perhitungan rentabilitas modal sendiri meski tidak mengalami peningkatan yang begitu besar namun keadaan masih menunjukkan bahwa rentabilitas modal sendiri keadaannya stabil.

Rentabilitas lebih penting dari masalah laba, karena laba yang besar belumlah merupakan ukuran bahwa perusahaan itu telah dapat bekerja secara efisien. Efisien baru dapat diketahui dengan membandingkan laba yang diperoleh dengan kekayaan atau modal yang menghasilkan laba tersebut atau dengan kata lain adalah menghitung rentabilitasnya. 


\section{Saran-Saran}

1. Perputaran modal kerja akan tetap efisien dan stabil jika pihak manajemen dalam perusahaan sebelumnya melakukan perencanaan dan pengendalian modal kerja secara tepat dan terarah, hal itu harus selalu dimonitor agar perputaran modal kerja tidak akan mengalami penurunan yang tidak di inginkan.

2. Dalam pengelolaan piutang agar suatu saat atau pada waktu-waktu tertentu tidak terjadi piutang tak tertagih, sehingga dalam pengelolaan piutang serta perputaran piutang tetap efisien dan sesuai apa yang ingin dicapai oleh perusahaan, maka perusahaan harus tetap melakukan pengendalian penagihan piutang terhadap nasabah agar periode perputaran piutang dapat terus stabil.

Adapun langkah-langkah dalam penagihan piutang terhadap nasabah adalah sebagai berikut:

a. Melakukan penagihan piutang atau kredit secara aktif, baik penyampaian secara langsung dengan mendatangi dan memberikan surat tagih kepada nasabah penunggak kredit atau dengan melalui media telekomunikasi berupa telepon.

b. Memberikan potongan bagi pelanggan yang telah melunasi kreditnya pada batas-batas waktu yang telah ditentukan.

c. Untuk mengantisipasi resiko tidak tertagihnya piutang nasabah di perusahaan, maka perusahaan dapat memberikan sangsi kepada debitur yang menunggak membayar sehingga debitur mampu membayar tepat pada waktunya.

d. Perusahaan harus lebih menekankan pada masalah promosi, baik melalui media cetak, elektronik maupun mengadakan penyuluhan-penyuluhan tentang manfaat kredit yang diberikan, sebab ujung tombak agar perusahaan tetap bisa tumbuh dan berkembang adalah terletak pada bagaimana cara perusahaan memperkenalkan produk yang di miliki agar dapat dikenal dan dipahami oleh masyarakat.

\section{DAFTAR PUSTAKA}

Bambang Riyanto. 1998. Dasar-Dasar Pembelanjaan Perusahaan. Edisi Empat. Cetakan kelima. Penerbit BPFE: Yogyakarta

Beaver, William., John W. Kennelly and William M. Voss. 1986. Predictive Ability as on Criteriafor Evaluation of Accounting Data. The Accounting Review (October). P 765-683.

Cho, L.Y., and K. Jung. (1991). Earnings Response Coefficients: A Synthesis of Theory and Empirical Evidence. Journal of Accounting Literature, Vol.10. pp 85-116.

Darmadji, Tjiptono, Fakhrudin, Hendy, M., 2001. Pasar Modal di Indonesia; Pendekatan Tanya Jawab. Salemba Empat, Jakarta. 
Fama, Eugee F 1980. Agency Problems and The Theory of the Firms. Journal of Political Economy. Vol 2. p 288-307

Fety, H. W., 2001. Pengaruh Beberapa Variabel Fundamental terhadap Harga Saham (Studi Kasus pada Perusahaan dengan Indeks LQ-45 di Bursa Efek Indonesia). Tesis: Program Pascasarjana Universitas Brawijaya, Malang.

Ghozali, Imam, 2001. Aplikasi Analisis Multivariate dengan Program SPSS. BP Universitas Diponegoro, Semarang.

Guidry, Flora., Leone. J. Andrew a nd Rock Simpson. 1999. Earnings Based Bonus Plans and Earnings Management By Business Units Managers. Journal Financial Management. P 113-142

Gulo, Y., (2000) Analisis Efek luas Pengungkapan Sukarela Dalam Laporan TahunanTerhadap Cost of Equiiy Capital Perusahaan. Jurnal Bisnis Keuangan ,

Gunarianto dan Nasri, M. (2008). Pengaruh Individual Rank, Pengalaman Kerja serta Skala Perusahaan Terhadap Hasil Kerja Auditor Intern (Studi terhadap Para Auditor Intern Emiten pada Sektor Manufaktur di Bursa

Gunarianto. (2004) Pengaruh Pengumuman Laporan Keuangan Terhadap Perubahan Harga Saham di Bursa Efek Jakarta. Laporan Penelitian LPPM UWG Mlg.

Syamsi, Ibnu. 1994. Pokok-pokok Organisasi dan Manajemen. PT. Bina Aksara: Jakarta

Jusup, Al. Haryono, 2005. Dasar-dasar Akuntasi, Edisi 6, Jilid 2, Universitas Gadjah Mada, Yogyakarta.

Key, Kimberly, G. 1997. Political Cost Incentives For Earnings Management in The Cable Television Industry. Journal of Financial and Economics. P 309-337

Marzuki. 2002. Metodologi Riset. Penerbit BPFE: Yogyakarta

Michel H.W dan Paul L.W. 1993. Metode dan Analisis. Jakarta: Erlangga.

Murwaningsari, Etty. (2008) Beberapa faktor yang memepengaruhi Earnings Response Coefficient (ERC). Simposium Nasional Pontianak

Napa J Awat. 1999. Manajemen Keuangan Pendekatan Matematis. Gramedia Pustaka Utama: Jakarta

Peraturan Pemerintah Republik Indonesia No 103 Tahun 2000 tentang Perusahaan Umum Pegadaian, Presiden Republik Indonesia, 2000.

Purnomo, Yugo, 1998. Keterkaitan Kinerja Keuangan dengan Harga Saham (Studi Kasus 5 Rasio Keuangan 30 Emiten di BEI Pengamatan 1992-1996). Usahawan No. 12 Tahun XXVII Desember, halaman 33-38, Jakarta.

Sundjaja, Ridwan S dan Inge Barlian. 2003. Manajemen Keuangan. Jilid 1. PT. Intan Sejati: Klaten

Riyanto, Bambang, 2001. Dasar - dasar Pembelanjaan Perusahaan. Yogyakarta BPFE Universitas Gadjah Mada.

S Munawir. 2002. Analisa Laporan Keuangan. Edisi Empat. Cetakan ketiga belas. Liberty: Yogyakarta

Santoso, Singgih, 2001. Buku Latihan Statistik Parametrik. PT Elex Media Komputindo Kelompok Gramedia, Jakarta.

Scott, Wilson. 1997. Some Economic Determinants of Time Series Properties of Earnings. Journal of Economics and financial. P 31-48 
94 MODERNISASI, Volume 9, Nomor 2, Juni 2013

Weston. J.F., and Copeland, 1996. Manajemen Keuangan. Terjemahan Jaka Wasana dan Kirbrandoko. Erlangga, Jakarta.

Y Sri Susilo, dkk. 2000. Bank dan Lembaga Keuangan Lain. Edisi 1. Salemba Empat: Jakarta 